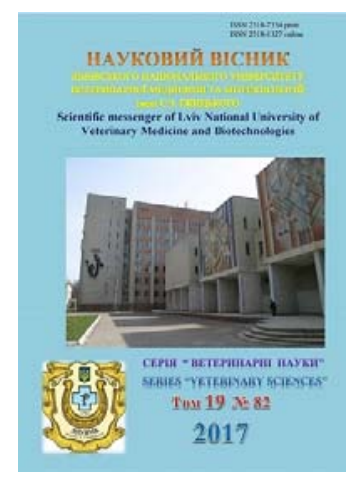

Науковий вісник Львівського національного університету ветеринарної медицини та біотехнологій імені С.З. Гжицького

Scientific Messenger of Lviv National University of Veterinary Medicine and Biotechnologies

doi:10.15421/nvlvet8217

ISSN 2518-7554 print

ISSN 2518-1327 online

$\underline{\text { http://nvlvet.com.ua/ }}$

УДК 636.92.053.112.385.4

\title{
Ріст і розвиток організму кролів за випоювання сполук силіцію
}

\author{
А.І. Іваницька ${ }^{1}$, Я.В. Лесик ${ }^{1}$, С.Й. Кропивка ${ }^{2}$, Н.К. Гойванович ${ }^{3}$ \\ nastya_ivanitska@ukr.net \\ ${ }^{1}$ Інститут біології тварин НААН, \\ вул. В. Стуса, 38, м. Львів, 79034, Україна; \\ ${ }^{2}$ Львівський національний університет ветеринарної медицини та біотехнологій імені С.3. Гэицького, \\ вул. Пекарська, 50, Львів, 79010, Україна; \\ ${ }^{3}$ Дрогобицький державний педагогічний університет імені Івана Франка \\ вул Івана Франка, 24, Дрогобич, 82100, Україна
}

\begin{abstract}
Наведено результати дослідження впливу випоювання впродовж 58 діб життя різних кількостей наносиліцію ицтрату, отриманого методом з використанням нанотехнології та метасилікату натрію, на ріст і розвиток організму кролів 110 добового віку. Встановлено вірогідні міжгрупові різниці передзабійної маси тіла і маси тушки у кролів, які споживали наносиліцію цитрат, щу свідчить про стимулювальний вплив органічної сполуки силічію на інтенсивність розвитку організму. Випоювання кролям наносилічію ичитрату порівняно з метасилікатом натрію та контрольною групою, в більшій мірі вплинуло на масу шкіри та масу печінки, ще позначилося підвищенням $(P<0,05)$ їх масометричних показників на 110 добу життя. Застосування органічної сполуки силічію у кількості 50 і 75 мкг $\mathrm{Si} / \kappa 2$ маси тіла, впродовж 58 діб сприяло активації обмінних прочесів у шкірі. Встановлено вірогідно вищі $(P<0,05)$ показники товщини дерми й підщкірної клітковини та загальної товщини шкіри кролів порівняно з контрольною групою. Проведеними дослідженнями встановлено більше виражений позитивний вплив на ріст і розвиток організму кролів органічної сполуки силіцію у кількості 50 i 75 мкг $\mathrm{Si} /$ к маси тіла порівняно з його неорганічною сполукою та контрольною групою.

Ключові слова: кролі, наносиліцію цичтрат, метасилікат натрію, маса тіла, маса внутрішніх органів, икіра, коефіціснт маси тіла.
\end{abstract}

\section{Рост и развитие организма кроликов при выпаивании соединенй кремния}

\author{
А.И. Иваницкая ${ }^{1}$, Я.В. Лесик ${ }^{1}$, С.И. Крапивка ${ }^{2}$, Н.К. Гойванович ${ }^{3}$ \\ nastya_ivanitska@ukr.net \\ ${ }^{1}$ Институт биологии животных НААН, \\ ул. В. Стуса, 38, г. Львов, 79034, Украина; \\ ${ }^{2}$ Львовский нацииональный университет ветеринарной медицины и биотехнологий имени С.3. Гжицкого, \\ ул. Пекарская, 50, г. Львов, 79010, Украина; \\ ${ }^{3}$ Дрогобычский государственный педагогический университет имени Ивана Франко, \\ ул. Ивана Франко, 24, Дрогобыч, 82100, Украина
}

\begin{abstract}
Приведены результаты исследования влияния выпаивания в течение 58 суток жизни различных количеств наносилиция ичттрата, полученного методом с использованием нанотехнологии и метасиликата натрия на рост и развитие организма кроликов 110-суточного возраста. Установлены вероятные межгрупповые различия предубойной массы тела и массы тушки у кроликов, которые потребляли наносилиция циттат, что свидетельствует о стимулирующем влиянии органического соединения кремния на интенсивность развития организма. Выпаивание кроликам наносилиция цитрата по сравнению с метасиликатом натрия и контрольной группой в большей степени повлияло на массу кожи и массу печени, что сказалось
\end{abstract}

Citation:

Ivanitskaya, A.I., Lesyk, Ya.V., Kropyvka, S.Y., Hoivanovych, N.K. (2017). Growth and development of the organism rabbits for the feeding of the silicon connection. Scientific Messenger LNUVMB, 19(82), 82-87. 
вероятным повышением (P < 0,05) их масометрических показателей на 110 сутки жизни. Применение органического соединения кремния в количестве 50 и 75 мкг Si/кг массы тела, в течение 58 суток способствовало активации обменных проиессов в коже. Установлены достоверно высшее $(P<0,05)$ показатели толщины дермы и подкожной клетчатки и общей толщчны кожи кроликов по сравнению с контрольной группой. Проведенными исследованиями установлено более выраженное положительное влияние на рост и развитие организма кроликов при выпаивании органического соединения кремния в количестве 50 и 75 мкг Si/кг массы тела по сравнению с его неорганическим соединением и контрольной группой.

Ключевье слова: кролики, наносилиция цчитрат, метасиликат натрия, масса тела, масса внутренних органов, кожа, коэффициент массы тела.

\title{
Growth and development of the organism rabbits for the feeding of the silicon connection
}

\author{
A.I. Ivanitskaya ${ }^{1}$, Ya.V. Lesyk ${ }^{1}$, S.Y. Kropyvka ${ }^{2}$, N.K. Hoivanovych ${ }^{3}$ \\ nastya_ivanitska@ukr.net \\ ${ }^{2}$ Institute of Animal Biology NAAS, \\ V. Stus Str., 38, Lviv, 79034, Ukraine; \\ ${ }^{2}$ Stepan Gzhytskyi National University of Veterinary Medicine and Biotechnologies Lviv, \\ Pekarska Str., 50, Lviv, 79010, Ukraine; \\ ${ }^{3}$ Drohobych Ivan Franko State Pedagogical University, \\ I. Franko Str., 24, Drogobych-82100, Ukraine
}

\begin{abstract}
The purpose of the study was to investigate the effect of putting up for 58 days life of various amounts of nanosilicon citrate infusion obtained by the method using nanotechnology and metasilicate sodium, on the growth and development of the body of the rabbits of the Hyla 110 of the diurnal age. The rabbits of the control group fed without restriction a balanced granulated feed with free access to water. Animals of the experimental groups I, II and III fed feed of the control group's diet and, during the day, dispensed the citrus application, accounting for 25; 50 and $75 \mu \mathrm{g} \mathrm{Si} / \mathrm{kg}$ body weight. The females of the IV and V experimental groups feed the diet of the control group and set the sodium metasilicate $\left(\mathrm{Na}_{2} \mathrm{SiO}_{3} \mathrm{H}_{2} \mathrm{O}\right)$ with water in an amount of 2.5 and $5.0 \mathrm{mg} \mathrm{Si} / \mathrm{kg}$ body weight, respectively. The trial lasted 68 days, including a preparatory period of 10 days, an experimental one of 58 days. On the 110-th day of life, animals of all groups were killed to determine the mass indices of carcasses, internal organs and skin. Exposure of nanosilicon citrate to animals in the I, II, and III experimental groups during 58 days was characterized by an increase in body weight of 4.0; 9.5 and $8.9 \%$, while the use of sodium metasilicate in $I V$ and V groups increased by 3.1 and $4.2 \%$ compared with the control group. The carcass weight correlation was correlated with body weight and in animals of groups II and III, respectively, was higher by 10.6 and $9.0 \%$, while in other experimental groups it was greater in the range from 2.4 to $2.9 \%$ compared with control. Research on the development of the body of rabbits indicated a tendency to a higher level of body mass index and internal organs in animal experimental groups than in the control, although the more pronounced differences were in rabbits I-III groups, which were deposited on nanosilicon citrus application. Ribbons infusion of citrate in comparison with metasilicate of sodium and control group, to a greater extent influenced the mass of the skin and the mass of the liver, which was reflected in an increase $(P<0.05)$ of their mass on 110 days of life. The use of an organic compound of silicon in the amount of 50 and $75 \mu \mathrm{g} \mathrm{Si/kg}$ of body weight, during 58 days, contributed to the activation of metabolic processes in the skin. Perhaps higher $(P<0.05)$ indices of the thickness of the dermis and subcutaneous fat and the total thickness of the skin of rabbits compared with the control group were established. The conducted studies showed more pronounced positive effects on the growth and development of the body of rabbits of the organic compound of silicon in the amount of 50 and $75 \mu \mathrm{g} \mathrm{Si} / \mathrm{kg}$ body weight in comparison with its inorganic compound and control group.
\end{abstract}

Key words: rabbit, nanosilicon citrate, sodium metasilicate, body weight, mass of internal organs, skin, body mass index.

\section{Вступ}

Сучасне промислове кролівництво передбачає утримання кролів спеціалізованих м'ясних порід, які виведені для технологій інтенсивного вирощування на якісних гранульованих кормах (de Blas and Wiseman, 2010). Для забезпечення високо рівня обміну речовин у високопродуктивних кролів необхідні збалансовані раціони за поживністю та оптимальним рівнем мікроелементів, в тому числі й Силіцію. Головною функцією Силіцію в організмі $є$ участь в різних проміжних реакціях обміну, як каталізатора і в якості елемента зв'язку, що забезпечує нормальний перебіг життєво важливих механізмів, допомагаючи з'єднувати клітинні молекули в єдину функціонуючу структуру (Sripanyakorn et al., 2009). Однак з'являється все більше наукових тверджень щодо потреби оптимальних кількостей біологічно доступного Si для функціонування кісток і сполучної тканини організму тварин
(Jugdaohsingh, 2007; Nielsen, 2014). У сполучній тканині Силіцій є структурною одиницею кислих мукополісахаридів і протеїнів, що зв'язує їх між собою в єдиний комплекс. Цей комплекс формується за рахунок валентних та гідрогенних зв'язків, що утворюється ортосиліконовою кислотою з атомами оксигену або атомами азоту поліпептидних і полісахаридних ланцюгів (Jugdaohsingh et al., 2008; Nielsen, 2014). Метаболізм Силіцію в організмі регулюється стероїдними і тіреоїдними гормонами, зокрема за стерилізації самиць зменшується його засвоєння у травному каналі та вміст у крові. Видалення у тварин наднирників, підшлункової та щитоподібної залоз порушувало обмін Силіцію в їхньому організмі (Jugdaohsingh et al., 2008; Macdonald et al., 2012). Доведено, що Силіцій в організмі тварин і людини міститься в усіх органах і тканинах. Силіцієва кислота частково замінює фосфорну в нуклеїнових кислотах, відіграючи активуючу роль у біосинтезі протеїну (Martin, 2007; Jugdaohsingh 
et al., 2010). Силіцій бере участь у синтезі колагену та активації гідроксильних ензимів шкіри, поліпшуючи iï еластичність та міцність. Відзначено, що фізіологічні концентрації ортосиліконової кислоти у шкірі стимулюють фібробласти для виділення колагену типу I (Jugdaohsingh et al., 2008).

У раціонах тварин Силіцій міститься у значних кількостях у вигляді окису силіцію та силікатів, проте через низьку біодоступність неорганічних сполук засвоєння організмом тварин є низьким. Результати проведених досліджень свідчать про можливість застосування у тваринництві наносполук мікроелементів, виготовлених методом нанотехнології (Villaverde, 2010; United States Government Accountability..., 2010). За сучасними поглядами, органічні сполуки на основі наночастинок мікроелементів порівняно 3 їхніми солями мінеральних кислот регулюють обмінні процеси в клітинах за принципом роботи наномеханізмів ( $\mathrm{Na}$ et al., 2010; Sri Sindhura et al., 2014). Bраховуючи, що Силіцій бере участь у багатьох біохімічних реакція організму, він має вибірковий вплив залежно від кількості та сполуки. Тому метою дослідження було вивчити вплив випоювання наносиліцію цитрату, отриманого методом нанотехнології та метасилікату натрію впродовж 58 діб на ріст і розвиток організму кролів 110-добового віку.

\section{Матеріал і методи досліджень}

Дослідження проводили на молодняку кролів породи Hyla у ТзОВ «Горлиця» с. Добряни Городоцького району Львівської області, поділених на шість груп (контрольну і п’ять дослідних), по 6 тварин у кожній (3 самці та 3 самиці), підібраних за принципом аналогів у віці 41 доби. Кролям контрольної групи згодовували без обмеження збалансований гранульований комбікорм з вільним доступом до води. Тваринам I, II i III дослідних груп згодовували корми раціону контрольної групи і впродовж доби випоювали наносиліцію цитрат, з розрахунку відповідно 25; 50 і 75 мкг $\mathrm{Si} /$ кг маси тіла. Розчин наносиліцію цитрату $\left(0,5\right.$ г/дм $\left.{ }^{3}, \mathrm{pH} 1,35\right)$ отримано від ТОВ «Наноматеріали i нанотехнології», м. Київ. Молодняку IV i V дослідних груп згодовували корми раціону контрольної групи і 3 водою задавали метасилікат натрію $\left(\mathrm{Na}_{2} \mathrm{SiO}_{3} \mathrm{H}_{2} \mathrm{O}\right)$ в кількості відповідно 2,5 і 5,0 мг $\mathrm{Si} /$ кг маси тіла. Дослід тривав 68 діб, в тому числі підготовчий період 10 діб, дослідний - 58 діб. На 110 добу життя тварин усіх груп забивали для визначення масометричних показників тушки, внутрішніх органів та шкіри. Шкіру зважували без кінцівок та голови і відбирали зразки в ділянці стегна. Для гістологічного дослідження зразки шкіри фіксували у $10 \%$ розчині нейтрального формаліну, зневоднювали, заливали в парафін, після отримання гістозрізів їх фарбували гематоксиліном і еозином та визначали товщину шарів під мікроскопом за допомогою окуляр-мікрометра, відповідно до методик, що описані у довіднику (Vlizlo et al., 2012). Усі маніпуляції з тваринами проводили відповідно до Європейської конвенції про захист хребетних тварин, які використовуються для експериментальних і наукових цілей. Цифрові дані опрацьовували статистично з використанням t критерію Стьюдента. Розраховували середні арифметичні величини (М) та похибки середніх арифметичних величин $( \pm \mathrm{m})$. Зміни вважали вірогідними за $\mathrm{P}<0,05$. Для розрахунків використано комп’ютерну програму Excel.

\section{Результати та їх обговорення}

Одержані результати дослідження свідчать, що ефект від застосування як органічної, так і неорганічної сполук Силіцію був неоднаковим. Зокрема, випоювання наносиліцію цитрату тваринам I, II і III дослідних груп впродовж 58 діб відзначилося підвищенням маси тіла відповідно на 4,0; 9,5 і 8,9\%, тоді як застосування метасилікату натрію у IV i V групах збільшилося на 3,1 i 4,2\% порівняно 3 контрольною групою (табл. 1). Оцінка росту тварин впродовж дослідження свідчить про позитивний вплив та вищу біодоступність в організмі молодняку кролів органічної сполуки силіцію порівняно з метасилікатом натрію та контролем, на що вказують й інші автори (Srinivas et al., 2010).

Таблиияя 1

Маса тіла і показники забою кролів за випоювання сполук силіцію, г, $(\mathrm{M} \pm \mathrm{m}, \mathrm{n}=6)$

\begin{tabular}{|c|c|c|c|c|c|c|}
\hline \multirow{2}{*}{ Показник } & \multicolumn{5}{|c|}{ Група } \\
\cline { 2 - 7 } & Контроль & Д-I & Д-II & Д-ІІІ & Д-IV & Д-V \\
\hline $\begin{array}{c}\text { Маса тіла перед } \\
\text { забоєм }\end{array}$ & $3216,6 \pm 58,06$ & $3348,1 \pm 41,53$ & $3525,3 \pm 55,18^{* *}$ & $3504,3 \pm 37,08^{* *}$ & $3319,3 \pm 44,64$ & $3354,3 \pm 48,95$ \\
\hline$\%$ до контролю & 100 & 104,0 & 109,5 & 108,9 & 103,1 & 104,2 \\
\hline Маса тушки & $1914,8 \pm 22,28$ & $1969,4 \pm 15,44$ & $2119,2 \pm 18,00^{* * *}$ & $2088,5 \pm 19,50^{* * *}$ & $1972,1 \pm 16,74$ & $1962,4 \pm 16,96$ \\
\hline$\%$ до контролю & 100 & 102,8 & 110,6 & 109,0 & 102,9 & 102,4 \\
\hline $\begin{array}{c}\text { Забійний вихід, } \\
\%\end{array}$ & $59,5 \pm 0,60$ & $59,1 \pm 1,05$ & $59,7 \pm 0,84$ & $59,6 \pm 0,58$ & $59,4 \pm 0,60$ & $58,5 \pm 0,95$ \\
\hline
\end{tabular}

Примітка: у цій і наступних таблицях вірогідність різниць між контролем і дослідом * $-\mathrm{P}<0,05 ; * *-\mathrm{P}<0,01 ; * * *-\mathrm{P}<0,001$

Показник маси тушки корелював з масою тіла і у тварин II і III груп був відповідно вищим на 10,6 i $9,0 \%$, тоді як у інших дослідних групах цей показник був більшим в межах від 2,4 до 2,9\% порівняно з контролем. Вищі показники маси тушки кролів дослідних груп порівняно 3 контролем можна пояснити позитивним впливом сполук силіцію на обмінні процеси, у т. ч. протеїнового обміну в їх організмі, оскільки Силіцій активує біосинтез колагену, який тісно пов'язаний 3 процесами формування кісткової і м'язової тканини організму (Jugdaohsingh et al., 2008), що найбільше було виражено у тварин II і III дослідних груп. Забійний вихід у кролів дослідних груп суттєво не зміню- 
вався і був найвищим у тварин II групи порівняно 3 контролем.

Дослідженнями розвитку організму кролів відзначено тенденцію до вищого рівня показників маси голови та внутрішніх органів у тварин дослідних груп, ніж у контролі, хоча більше виражені різниці були у кролів I-III груп, яким випоювали наносиліцію цитрат (табл. 2). Найбільше виражені вірогідні різниці відзначено у масі печінки та шкіри кролів дослідних груп порівняно 3 контролем. Так, вища маса печінки у тварин дослідних груп, крім V групи, з вірогідними різницями для кролів II і III дослідних груп порівняно
3 контролем, може свідчити про активацію обміну протеїну в їхньому організмі, що більше було вираженим за дії органічної сполуки силіцію. Відомо, що печінка у кролів відносно маси тіла, порівняно 3 іншими сільськогосподарськими тваринами, $є$ найбільшим внутрішнім органом, що забезпечує сталість внутрішнього середовища систем організму. У клітинах печінки проходять метаболічні процеси біосинтезу і розчеплення протеїну, що забезпечує організм необхідними енергетичними та пластичними матеріалами.

Показники маси голови, шкіри та внутрішніх органів кролів за випоювання сполук силіцію, г $(M \pm m, n=6)$

\begin{tabular}{|c|c|c|c|c|c|c|}
\hline \multirow{2}{*}{ Показник } & \multicolumn{5}{|c|}{ Група } \\
\cline { 2 - 7 } & Контроль & Д-I & Д-ІІ & Д-III & Д-IV & Д-V \\
\hline Голова & $153,9 \pm 2,17$ & $156,1 \pm 3,48$ & $162,5 \pm 5,65$ & $162,7 \pm 3,99$ & $153,7 \pm 3,09$ & $156,3 \pm 3,50$ \\
\hline$\%$ до контролю & 100 & 101,4 & 105,5 & 105,7 & 99,8 & 101,5 \\
\hline Легені & $15,9 \pm 0,29$ & $16,0 \pm 0,41$ & $16,9 \pm 0,65$ & $17,0 \pm 0,50$ & $17,1 \pm 0,72$ & $16,3 \pm 0,38$ \\
\hline$\%$ до контролю & 100 & 100,6 & 106,2 & 106,9 & 107,5 & 102,5 \\
\hline Серце & $10,1 \pm 0,39$ & $10,7 \pm 0,49$ & $10,7 \pm 0,41$ & $10,8 \pm 0,49$ & $10,1 \pm 0,35$ & $10,1 \pm 0,40$ \\
\hline$\%$ до контролю & 100 & 105,9 & 105,9 & 106,9 & 100,0 & 100,0 \\
\hline Нирки & $20,0 \pm 0,29$ & $20,6 \pm 0,43$ & $20,7 \pm 0,68$ & $20,9 \pm 0,58$ & $20,2 \pm 0,47$ & $20,5 \pm 0,53$ \\
\hline$\%$ до контролю & 100 & 103,0 & 103,5 & 104,5 & 101,0 & 102,5 \\
\hline Селезінка & $1,95 \pm 0,10$ & $1,96 \pm 0,12$ & $2,01 \pm 0,10$ & $2,13 \pm 0,08$ & $1,98 \pm 0,12$ & $1,96 \pm 0,10$ \\
\hline$\%$ до контролю & 100 & 100,5 & 103,0 & 109,2 & 101,5 & 100,5 \\
\hline Печінка & $97,2 \pm 2,93$ & $100,2 \pm 2,03$ & $106,1 \pm 2,26^{*}$ & $105,7 \pm 1,86^{*}$ & $100,6 \pm 1,38$ & $98,8 \pm 2,51$ \\
\hline$\%$ до контролю & 100 & 103,0 & 109,1 & 108,7 & 103,4 & 101,6 \\
\hline Шкіра & $456,6 \pm 5,57$ & $463,3 \pm 4,94$ & $475,0 \pm 4,28^{*}$ & $471,6 \pm 3,07 *$ & $468,3 \pm 6,01$ & $458,3 \pm 6,00$ \\
\hline$\%$ до контролю & 100 & 101,4 & 104,0 & 103,2 & 102,5 & 100,3 \\
\hline
\end{tabular}

Порівняльний аналіз маси шкіри кролів дослідних груп показав вищі їхні масометричні показники, ніж у тварин контрольної групи. Так, маса шкіри тварин II і III дослідних груп була відповідно вищою на 4,0 i $3,2 \%$ (Р < 0,05) за тенденції до вищих показників цього органу в I, IV i V групах порівняно з контролем. Результати досліджень маси шкіри свідчать про більшу біодоступність органічної сполуки силіцію, ніж неорганічної в організмі кролів, що більше було виражено у тварин II і III дослідних груп.

Гістологічними дослідженнями шкіри кролів встановлено вплив кількості та сполуки силіцію на тов- щину iї шарів, за винятком епідермісу, який суттєво не змінювався у тварин дослідних груп порівняно 3 контрольною (табл. 3). Зокрема, товщина дерми й підшкірної клітковини та загальна товщина шкіри кролів II і III дослідних груп була вірогідно вищою на 5,4 і 5,3\% (P < 0,05) порівняно з контрольною групою. Це може свідчити про позитивний вплив наносиліцію цитрату на активацію метаболічних процесів у дермальному шарі шкіри кролів, тоді як застосування матасилікату натрію тваринам IV i V груп позначилося тенденцією до його збільшення відповідно на 2,8 i 2,6\% порівняно $з$ контролем.

Товщина шкіри кролів у ділянці стегна за випоювання сполук силіцію, мк $(\mathrm{M} \pm \mathbf{m}, \mathbf{n}=4)$

Таблиця 3

\begin{tabular}{|c|c|c|c|}
\hline \multirow{2}{*}{ Група } & \multicolumn{2}{|c|}{ Шари шкіри } & \multirow{2}{*}{ Загальна товщина шкіри } \\
\cline { 2 - 3 } & епідерміс & дерма і підшкірна клітковина & $169,2 \pm 2,83$ \\
\hline Контроль & $3,2 \pm 0,13$ & $165,9 \pm 2,72$ & $170,3 \pm 2,60$ \\
\hline Д-I & $3,6 \pm 0,17$ & $166,7 \pm 2,44$ & $178,4 \pm 1,73^{*}$ \\
\hline Д-ІІ & $3,3 \pm 0,02$ & $175,0 \pm 1,72^{*}$ & $178,2 \pm 1,87^{*}$ \\
\hline Д-III & $3,4 \pm 0,14$ & $174,8 \pm 1,86^{*}$ & $174,0 \pm 1,01$ \\
\hline Д-IV & $3,4 \pm 0,15$ & $170,6 \pm 0,89$ & $173,8 \pm 2,11$ \\
\hline Д-V & $3,5 \pm 0,10$ & $170,3 \pm 2,40$ & \\
\hline
\end{tabular}

За літературними даними (Jouni Uitto, 2008), в організмі тварин найбільша кількість Силіцію міститься в шкірі та волоссі. У шкірі Силіцій бере участь у синтезі колагену, активує гідроксильні ензими, входить до складу фібрилярних білків колагену і еластину, надаючи сполучній тканині міцність і пружність. Можливо, застосування оптимальних кількостей наносиліцію цитрату в раціоні кролів II і III дослідних груп позитивно вплинуло на обміні процеси у шкірі, а саме синтез колагену в результаті чого системі пучки колагенових волокон, які формують шкірний покрив були більш товщими, а їх компонування більш щільним, що загалом позначилося на товщині іï шарів.

Випоювання органічної та неорганічної сполук силіцію призвело до зміни відносних показників забою кролів, які були у межах фізіологічних параметрів до 
маси тіла (табл. 4). Зокрема, відзначено тенденцію до меншого коефіцієнту маси голови та шкіри кролів дослідних груп порівняно 3 контрольною, що може свідчити за позитивний вплив сполук силіцію на розвиток їх маси тіла. Коефіцієнт маси селезінки тварин
I, II i V дослідних груп був вірогідно меншим $(\mathrm{P}<0,05)$ порівняно 3 контролем. Тимчасом як коефіцієнти маси інших внутрішніх органів кролів дослідних груп суттєво не відрізнялися від контрольної групи тварин.

Таблиця 4

Коефіцієнти маси голови, внутрішніх органів та шкіри кролів за випоювання сполук силіцію, \%

$(\mathbf{M} \pm \mathbf{m}, \mathbf{n}=\mathbf{6})$

\begin{tabular}{|c|c|c|c|c|c|c|}
\hline \multirow{2}{*}{ Показник } & \multicolumn{7}{|c|}{ Група } \\
\cline { 2 - 7 } & Контроль & Д-І & Д-ІІ & Д-ІІІ & Д-IV & Д-V \\
\hline $\begin{array}{c}\text { Відсоток до маси } \\
\text { тіла: голова }\end{array}$ & $4,78 \pm 0,11$ & $4,63 \pm 0,11$ & $4,56 \pm 0,10$ & $4,58 \pm 0,11$ & $4,63 \pm 0,12$ & $4,61 \pm 0,11$ \\
\hline легені & $0,46 \pm 0,01$ & $0,46 \pm 0,01$ & $0,47 \pm 0,01$ & $0,48 \pm 0,01$ & $0,48 \pm 0,01$ & $0,47 \pm 0,01$ \\
\hline серце & $0,31 \pm 0,01$ & $0,32 \pm 0,01$ & $0,30 \pm 0,01$ & $0,31 \pm 0,01$ & $0,30 \pm 0,01$ & $0,30 \pm 0,01$ \\
\hline нирки & $0,61 \pm 0,01$ & $0,61 \pm 0,02$ & $0,58 \pm 0,01$ & $0,59 \pm 0,01$ & $0,60 \pm 0,01$ & $0,60 \pm 0,01$ \\
\hline селезінка & $0,06 \pm 0,003$ & $0,05 \pm 0,003^{*}$ & $0,05 \pm 0,003^{*}$ & $0,06 \pm 0,002$ & $0,06 \pm 0,003$ & $0,05 \pm 0,003^{*}$ \\
\hline печінка & $3,01 \pm 0,05$ & $2,99 \pm 0,05$ & $3,02 \pm 0,03$ & $3,01 \pm 0,04$ & $3,03 \pm 0,06$ & $2,94 \pm 0,05$ \\
\hline шкіра & $14,20 \pm 0,10$ & $13,84 \pm 0,21$ & $13,48 \pm 0,23$ & $13,46 \pm 0,13$ & $14,10 \pm 0,15$ & $13,67 \pm 0,22$ \\
\hline
\end{tabular}

Отже, одержані дані росту організму, масометричних показників тушки та внутрішніх органів можуть вказувати про позитивний вплив застосування органічної сполуки силіцію на інтенсивність розвитку організму та окремих внутрішніх органів, що сприяє посиленому перебігу обмінних процесів і нарощуванню маси тіла.

\section{Висновки}

1. Випоювання у раціоні кролів наносиліцію цитрату у кількості 50 і 75 мкг $\mathrm{Si} /$ кг маси тіла, зумовлювало зміни показників росту і розвитку їхнього організму, що характеризувалося вірогідно вищою масою тіла, масою тушки, печінки та шкіри тварин дослідних груп порівняно з контролем, що може свідчити про дозозалежний вплив органічної сполуки силіцію.

2. Застосування метасилікату натрію у кількості 2,5 і 5,0 мг $\mathrm{Si} /$ кг маси тіла супроводжувалося тенденцією до підвищення маси тіла, маси внутрішніх органів та шкіри, що більше було виражено у тварин, які споживали меншу дозу неорганічної сполуки Si.

Перспективи подальших досліджень. Наступні дослідження будуть спрямовані на вивчення оптимальних кількостей органічної та неорганічної сполук силіцію на відтворну здатність кролематок та життєздатність підсисного молодняку.

\section{Бібліографічні посилання}

de Blas, C., Wiseman, J. (2010). Nutrition of the Rabbit, 2nd Edition. Library of Congress Cataloging-inPublication Data.

Sripanyakorn, S., Jugdaohsingh, R., Dissayabutr, W., Anderson, S.H., Thompson, R.P., Powell, J.J. (2009). The comparative absorption of silicon from different foods and food supplements. Br. J. Nutr., 102, 825834.

Jugdaohsingh, R. (2007). Silicon and bone health. J. Nutr. Health Aging, 11, 99-110.

Nielsen, F.H. (2014). Update on the possible nutritional importance of silicon. J. Trace Elem. Med. Biol. 28, 379-382.
Jugdaohsingh, R., Calomme, M.R., Robinson, K., Nielsen, F., Anderson, C., D'Hease, P. (2008). Increased longitudinal growth in rats on a silicondepleted diet. Bone. 43, 596-606.

Jugdaohsingh, R., Kinrade, S.D., Powell, J.J. (2008). Is there a biochemical role for silicon? Metal Ions in Biology and Medicine. Paris: John Libbey Eurotext. X, 45-55.

Macdonald, H.M., Hardcastle, A.E., Jugdaohsingh, R., Reid, D.M., Powell, J.J. (2012). Dietary silicon interacts with oestrogen to influence bone health: evidence from the Aberdeen Prospective Osteoporosis Screening Study. Bone. 50, 681-687.

Martin, K.R. (2007). The chemistry of silica and its potential health benefits. Journal of Nutrition Health \& Aging, 94-98.

Jugdaohsingh, R., Anderson, C., Lakasing, L., Sripanyakorn, S., Ratcliffe, S., Powell, J.J. (2010). Serum silicon concentrations in pregnant women and newborn babies. Br. J. Nutr. 110, 2004-2010.

Jugdaohsingh, R., Calomme, M.R., Robinson, K., Nielsen, F., Anderson, S.H., D'Haese, P. (2008). Increased longitudinal growth in rats on a silicondepleted diet. Bone. 43, 596-606.

Villaverde, A. (2010). Nanotechnology, bionanotechnology and microbial cell factories. Microbial Cell Factories. 9, 53-56.

United States Government Accountability Office: Report on nanotechnology: nanomaterials are widely used in commerce, but EPA faces challenges in regulating risk. Int J Occup Environ Health 2010, 16(4), 525539.

Na, M., Park, H., Ahn, M. (2010). Synthesis of organicinorganic hybrid sols with nanosalica particles and organoalkokysilanes for transparent and high-thermalresistance coating films using solgel reaction. J. Nanosci. Nanotechnol. 10(10), 6992-6995.

Sri Sindhura, K., Selvam, P.P., Prasad, V., Hussain, O.M. (2014). Synthesis, characterization and evaluation of effect of phytogenic zinc nanoparticles on soil exoenzymes. Appl Nanosci. 4, 819-827.

Vlizlo, V.V., Fedoruk, R.S., Ratych, I.B. (2012). Laboratorni metody doslidzhen $\mathrm{u}$ biolohii, 
tvarynnytstvi ta veterynarnii medytsyni: dovidnyk. SPOLOM (in Ukrainian).

Official Journal of the European Union L276/33, 2010. Directive 2010/63/EU of The European Parliament and of The Council of 22 September 2010 on the protection of animals used for scientific purposes. 86/609/EC. 20.10.2010.

Srinivas, P.R., Philbert, M., Vu, T.Q., Huang, Q., Kokini, J.L., Saltos, E., Chen, H., Peterson, C.M., Friedl, K.E., McDade-Ngutter, C., Hubbard, V., Starke-Reed, P., Miller, N., Betz, J.M., Dwyer J., Milner, J., Ross, S.A.
(2010). Nanotechnology research: applications in nutritional sciences. Journal of Nutrition. 140, 119-124.

Jouni Uitto, M.D. (2008). The role of Elastin and Collagen in Cutaneous Aging: Intrinsec Aging Versus Photoexposure. J. Drugs Dermatol. 7, 12-16.

Received 3.10.2017

Received in revised form 26.10.2017

Accepted 2.11.2017 